TITLE:

\title{
Effect of Persistent Activation of Phosphoinositide 3-kinase on Heart(Abstract_要旨)
}

\section{$\operatorname{AUTHOR}(S)$ :}

Niizuma, Shinichiro

\section{CITATION:}

Niizuma, Shinichiro. Effect of Persistent Activation of Phosphoinositide 3-kinase on Heart. 京都大学, 2012, 博士(医学)

ISSUE DATE:

2012-09-24

URL:

http://hdl.handle.net/2433/160967

RIGHT: 


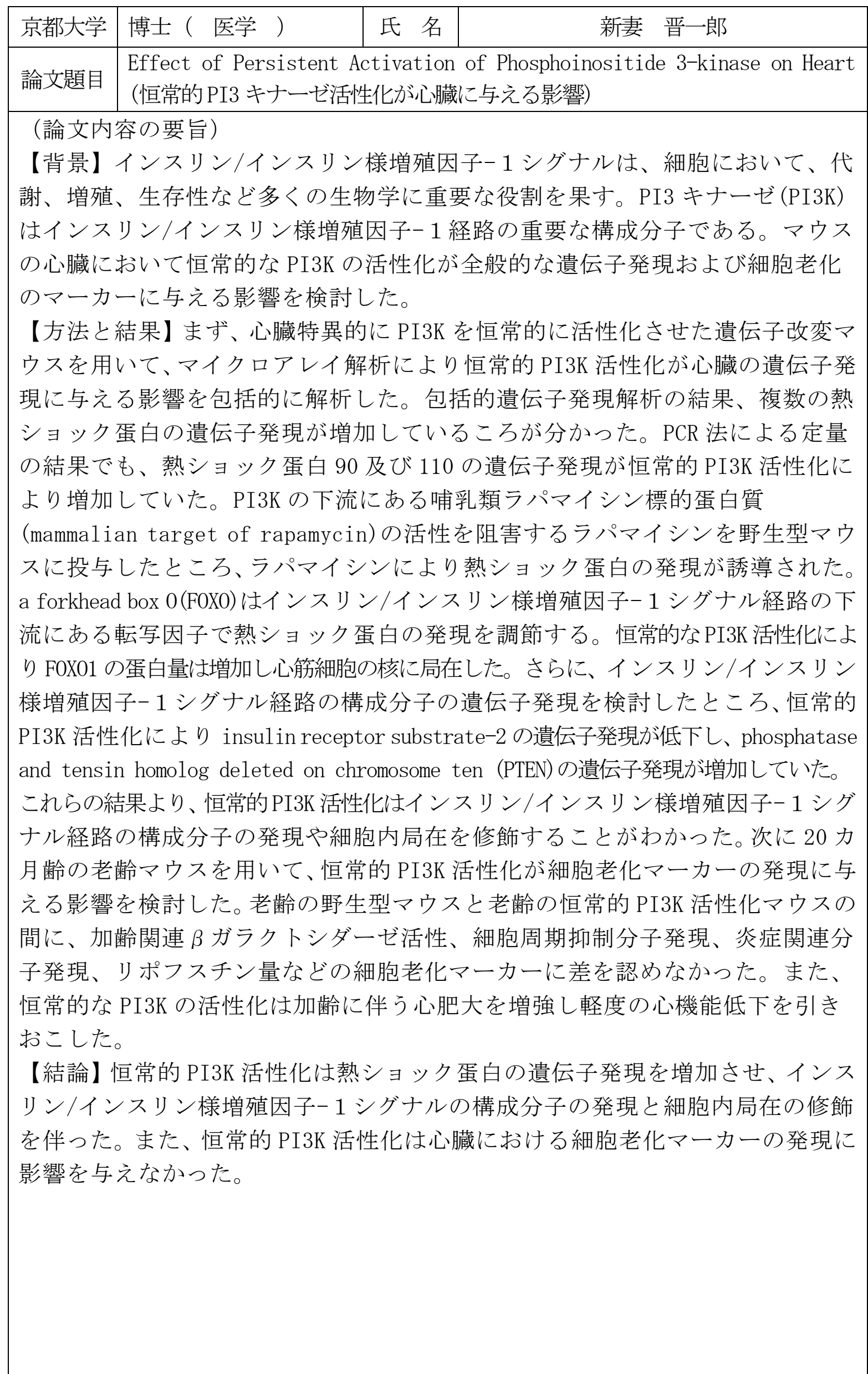

（論文審査の結果の要旨）

加齢は心血管疾患発症の大きな危険因子である。インスリン/インスリン様 増殖因子- 1 ( Ins/IGF-1) シグナル伝達経路は、細胞の代謝、増殖、生存性な どに重要な役割を果している。PI3K は Ins/IGF-1 経路の重要な構成分子で女 る。心臓特異的にPI3K を恒常的に活性化させた遺伝子改変マウスの心臓を用 いて、マイクロアレイ解析により心臓の遺伝子発現に与える影響を包括的に 解析したところ、複数の熱ショック蛋白の遺伝子発現が増加していた。恒常的 な PI3K 活性化により Ins/IGF-1 経路の下流に存在する転写因子 FOX01 の蛋白量か 増加し心筋細胞の核に局在した。また、恒常的 PI3K 活性化により、Ins/IGF-1 経 路の構成分子の遺伝子発現が修飾されていた。老齢マウスを用いた検討では、恒 常的 PI3K 活性化は細胞老化マーカーに影響を与えなかった。以上、恒常的 PI3K 活性化が、加齢に伴う心肥大を増強し軽度の心機能低下を引き起こすことを 見出した。恒常的 PI3K 活性化は、タンパク質品質管理に関与する熱ショック 蛋白質の遺伝子発現を増加させ、細胞内 $\mathrm{Ins} / \mathrm{IGF}^{-1}$ 経路の構成分子の発現と 局在を修飾した。

以上の研究は心臟における細胞内 Ins/IGF-1 経路の役割の解明に貢献し、心不全の 病態解明に寄与寸るところが多い。

したがって、本論文は博士（医学）の学位論文として価值あるものと認める。 なお、本学位授与申請者は、平成 24 年 8 月 8 日実施の論文内容とそれに関連した 試問を受け、合格と認められたものである。 